\title{
PERANCANGAN GAME 2 DIMENSI PETUALANGAN ANAK MENYELAMATKAN ORANGTUA SEBAGAI MEDIA EDUKATIF BAGI ANAK DENGAN METODE WATERFALL
}

\author{
Nurlaili Khairani, Juniardi Nur Fadila, Fressy Nugroho \\ Program Studi Teknik Informatika, Universitas Islam Negeri Maulana Malik Ibrahim Malang \\ J1. Gajayana No. 50, Dinoyo, Kec. Lowokwaru, Kota Malang \\ 18650057@student.uin-malang.ac.id, juniardi.nur@uin-malang.ac.id, fresy@ti.uin- \\ malang.ac.id
}

\begin{abstract}
The rapid development of technology and information has resulted in a lot of competition in all fields, one of which is education. This affects the education of educators in educating their students. They are guided to provide education that is fun and attracts children's attention. One way to increase children's interest in learning can be done by playing games. Games are games that are carried out with predetermined rules so that someone wins or loses, usually the game is played for refreshing, or filling spare time. There are 2D and 3D game types. 2D games have objects that are only in one plane and their movement is limited to that plane. The movement of objects from 2D games is only left and right. So to improve the quality of children's learning, 2D-based educational games are designed which aim as a place to play and learn. The game design uses the waterfall method which is made sequentially so that it will gradually be completed systematically and cannot pass through the stages. In this game the player will run the character so that he meets the parents and tries to help the parents' problems. This is a moral message for every player. This children's adventure game is a means for children to play and learn easily because it can be accessed anywhere and anytime.
\end{abstract}

Keywords - 2D Game, Game Engine, Unity, C \#, waterfall

\begin{abstract}
Abstrak - Perkembangan teknologi dan informasi yang semakin pesat mengakibatkan banyak persaingan pada segala bidang, salah satunya yaitu bidang pendidikan. Hal tersebut mempegaruhi edukasi bagi para pendidik dalam mengajar anak didiknya. Mereka dituntun untuk memberikan edukasi yang menyenangkan serta menarik perhatian anak-anak. Dalam meningkatkan minat anak dalam belajar salah satunya dapat dilakukan dengan bermain game. Game merupakan permainan yang dilakukan dengan aturan yang sudah di tetapkan sehingga terdapat kemenangan atau kekalahan, biasanya game dimainkan untuk refreshing, atau mengisi waktu luang. Terdapat jenis game 2D dan 3D. Game 2D memiliki objek yang hanya lerletak pada satu bidang serta gerakannya terbatas pada bidang tersebut. Gerakan objek dari game 2D hanya ke kiri dan ke kanan. Maka untuk meningkatkan kualitas pembelajaran anak dirancanglah game edukasi yang berbasis 2D yang bertujuan sebagai wadah dalam bermain serta belajar. Perancangan game menggunakan metode waterfall yang dibuat secara berurutan sehingga tahapan demi tahapan akan diselesaikan secara sistematis dan tidak dapat melewati tahapan. Didalam game pemain akan menjalankan karakter sehingga bertemu dengan orangtua dan berusaha membantu kendala orangtua tersebut. Hal ini menjadi pesan moral bagi tiap pemain. Game petualangan anak ini menjadi sarana bagi anak-anak untuk bermain dan belajar dengan mudah karena dapat diakses dimana dan kapan saja.
\end{abstract}

Kata Kunci - 2D Game, Game Engine, Unity, C \#, waterfall

\section{PENDAHULUAN}

Game semakin berkembang pesat hari demi hari. Perkembangan ditandai dengan semakin banyaknya para gamers pemula hingga pro players membuat konten ketika bermain game di platform youtube. Game yang dimainkan bervariasi dari yang gratis hingga berbayar. Terdapat banyak genre game yang dapat dimainkan salah satunya game petualang. Game petualang menekankan cerita yang didalam game dan juga memiliki tokoh protagonis. Karakter yang terdapat dalam dunia game akan diamati bahkan ditiru dalam kehidupan nyata. Namun tidak dapat dipungkiri selain adanya nilai positif maka terdapat juga nilai negative.

Oleh karna itu, pada zaman milenial ini, peningkatan kualitas pada bidang pendidikan semakin pesat. Sehingga mutu dari generasi terdidik semakin tinggi. Pendidikan menjadi landasan bagi anak-anak dalam menyaring dampak dari kemajuan teknologi. Banyak faktor yang mendorong hal tersebut, salah satunya yaitu bermain game. Dulunya bermain game dianggap hanya menghabiskan waktu dan tidak ada manfaatnya, namun, seiring dengan berjalannya waktu anggapan tersebut dapat dipatahkan. Ketika anak-anak 
dapat mengambil pesan moral yang dikemas dalam aplikasi game.

Kesenangan yang timbul akibat bermain game mengakibatkan tersainginya kesadaran dalam belajar dan waktu yang dibutuhkan dalam menyelesaikan suatu permainan terbilang cukup lama, sehingga dapat menguras habis waktu belajar. Maka diperlukan sebuah trik untuk menggabungkan kedua hal tersebut, yaitu sebuah game dengan konsep edukasi supaya ketika bermain game maka dapat sambil belajar.

Konsep game ini dirancang dengan metode waterfall. Metode waterfall merupakan sebuah metode yang pengembangan sistem kemudian dilakukan pembuatan sistem yang berjalan. Pengerjaan dari metode ini berurutan dan sistematis. Tiap tahapan akan diselesaikan secara tuntas kemudian baru menuju tahapan berikutnya sehingga pengerjaan per tahapan tidak dapat dilewati. Berdasarkan pandangan tersebut maka peneliti menggunakan metode ini dalam perancangan game edukatif bagi anak. Yang harapannya dapat menumbuhkan jiwa suka menolong bagi seseorang yang merupakan anjuran pada agama. Sehingga peneliti membuat sarana belajar anak lewat Perancangan Game 2 dimensi petualangan anak menyelamatkan orangtua sebagai Media Edukatif bagi anak dengan menggunakan metode Waterfall.

\section{KERANGKA TEORI}

\section{A. Game Edukasi}

Game merupakan sebuah sistem yang didalamnya terdapat player yang akan menemui suatu konflik yang dimainkan dengan aturan-aturan tertentu dan adanya keluaran berupa hasil dari suatu konflik yang dapat diselesaikan[1]. Dalam game terdapat target yang akan dicapai seperti level per level maupun penyelesaian game. Pada game terdapat suatu rancangan berupa tampilan yang didesain menarik supaya dapat menarik pemain untuk bermain game tersebut. Game edukasi merupakan sebuah permainan berbasis teknologi yang dirancang sebagai media pengajar berupa materi[2].

Jenis dari game disebut dengan genre. Genre pada game yang ini yaitu petualangan. Game petualangan adalah sebuah game yang mempunyai cerita interaktif mengenai karakter yang dikendalikan oleh pemain[3]. Pada game petualang menekankan pada jalan cerita dari game.

\section{B. Unity}

Unity merupakan suatu aplikasi yang digunakan untuk pengembangan game multi platform, seperti game pada perangkat komputer, android, iPhone, bahkan X-BOX. Unity mengembangkan game 2D maupun 3D yang menggunakan proses visual dan script [4]. Unity dapat berbasis games online yang mana diperlukannya sebuah plugin berupa unity web player. Pengoperasian unity terbilang mudah, software dapat di download pada situs resmi unity dan menjalankan apliaksinya tidak perlu koneksi dari internet. Terdapat dua versi lisensi yang ditawarkan oleh unity yaitu unity pro dan unity. Versi unity pro yaitu berbayar dan menawarkan render efek texture sedangkan versi unity yaitu gratis yang memperlihatkan game untuk web. Perkembangan unity terbilang cepat karena free user serta banyak turorial-tutorial yang mudah untuk dicari dan dipelajari.

\section{C. $C \#$}

C\# salah satu bahasa pemrograman yang sederhana yang dikembangkan oleh Microsoft. C\# merupakan Bahasa pemrograman yang digunakan untuk membuat aplikasi berbasis windows, web serta aplikasi yang berbasis web service[5]. Bahasa $\mathrm{C \#}$ dipengaruhi oleh berbagai macam bahasa lain seperti java dan delphi. Bahasa C\# bersifat general-purpose dan sederhana yang mampu menulisa program aplikasi dengan baik.

\section{2 Dimensi}

2 Dimensi memiliki 2 sisi yaitu bagian $\mathrm{X}$ dan $\mathrm{Y}$. Gambar 2D dapat dibuat menggunakan Vektor atau Bitmap. Pada game 2D Keseluruhan objek dan gerakan karakter hanya terbatas pada satu bidang yang datar yang dinamakan StaticView. Gerakan yang dapat dilakukan oleh game 3D hanya vertical dan horizontal. Side Scrolling View mengacu pada objek dan gambar latar yang dapat bergerak ke kiri maupun ke kanan berdasarkan kecepatan dari karakter yang dimainkan.

\section{METODE PENELITIAN}

Pada penelitian ini menggunakan metode waterfall yang mana tahap awalnya yaitu melakukan perancangan mengenai pemodelan supaya dapat mengetahui batasan dari masalah pada penerapan sistem sehingga pembuatan sistem dapat berurutan sesuai dengan model dari waterfall[6].

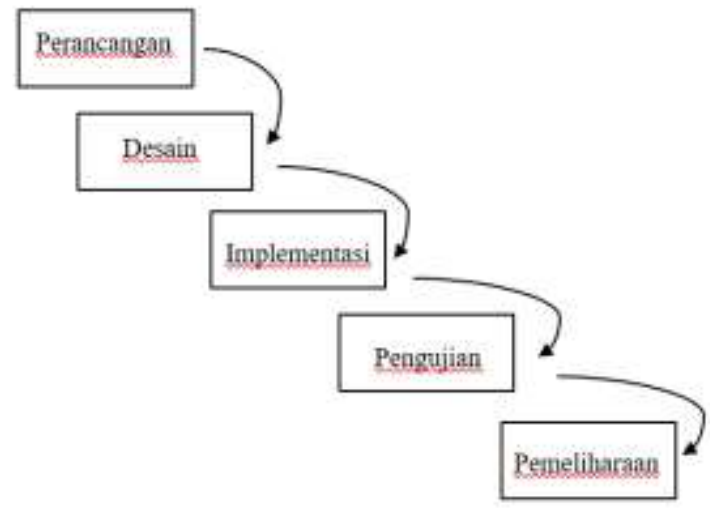

Gambar 1. Model Waterfall

\section{Perancangan}


Tahapan ini memerluakan rancangan yang ditentukan berupa tujuan dibuatnya game. Yakni sebagai media bermain sambil belajar supaya lebih menarik dan terhibur. Dilakuakan persiapan pembuatan game, seperti hardware maupun software yang akan digunakan selama proses pembuatan game.

\section{Desain}

Pada tahapan ini dilakukan pembuatan desain berupa alur game, asset yang dibutuhkan dalam pembuatan game, dan tampilan dari game agar sesuai dengan latar yang dipakai.

2.1 Flowchart

Flowchart merupakan gambaran urutan-urutan intruksi yang menjadi pedoman pengguna sehingga dapat mengerti alur dari game[7]. Flowchart menjelaskan alur dari sistem kerja yang terdapat dalam game petualangan anak.

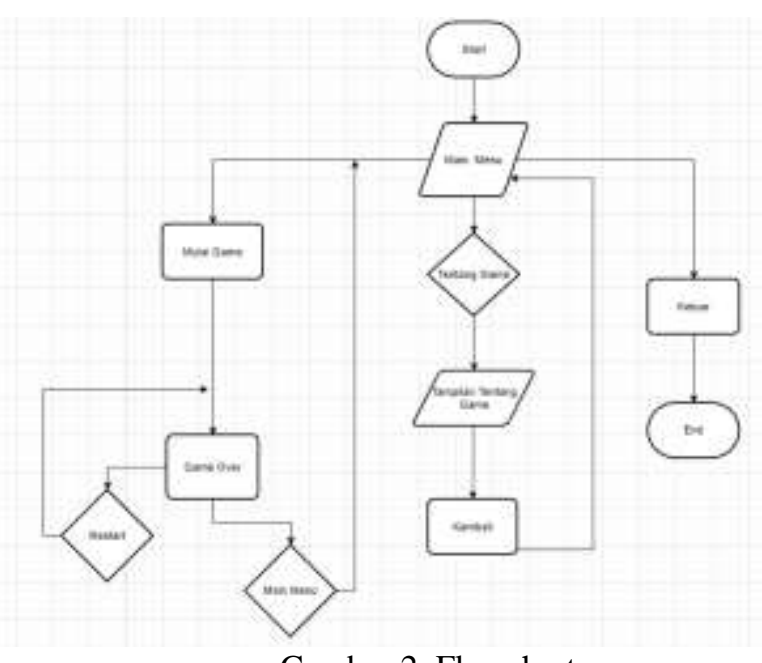

Gambar 2. Flowchart

\subsection{Use Case Diagram}

Use case diagram berguna sebagai pemodelan suatu sistem atau suatu perangkat lunak yang dilihat dari sisi pengguna atau usernya yang ada diluar sistem[8]. Pemodelan ini memberikan jabaran tentang intraksi yang dilakukan user dengan sistem yang akan dibangun.

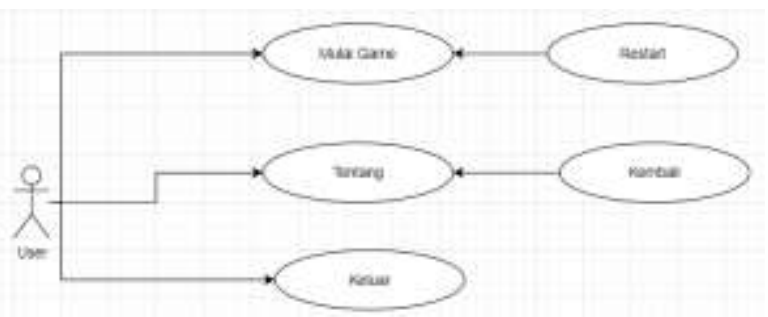

Gambar 3. Use Case Diagram

\section{Implementasi}

Pada tahapan ini dilakukan pengkodean yang nantinya akan menghasilkan suatu sistem. Coding dibuat untuk mempermudah dalam membangun sistem sehingga tahapan ini merupakan tahapan yang membutuhkan logika.Bahasa yang digunakan yaitu $\mathrm{C \#}$

4. Pengujian

Pada tahapan ini apabila game yang sudah dibangun selesai maka akan dilakukan pengujian dengan cara menjalankan program atau sistem. Dalam pengujian dapat diamati apakah sistem sudah berjalan dengan baik serta tampilan interface sesuai dengan harapan[9]. Kemudian memeriksa jika terdapat kesalahan ketika menjalanakan sistem tersebut atau tidak ada ada kesalahan sehingga sistem dapat berjalan dengan lancer ketika dimainkan oleh user.

5. Pemeliharaan

Tahapan terakhir yaitu pemeliharaan, yang mana sistem yang sudah jadi akan dijalankan oleh user. Dan dilakukan pemeliharan berupa perbaikan kesalahan dari sistem dan peningkatan sistem untuk memenuhi adanya kebutuhan baru dari user. Pemeliharaan berupa hardware dan software berguna untuk mengembangkan implementasi dari unit sistem[10].

\section{HASIL DAN PEMBAHASAN}

1. Main Menu

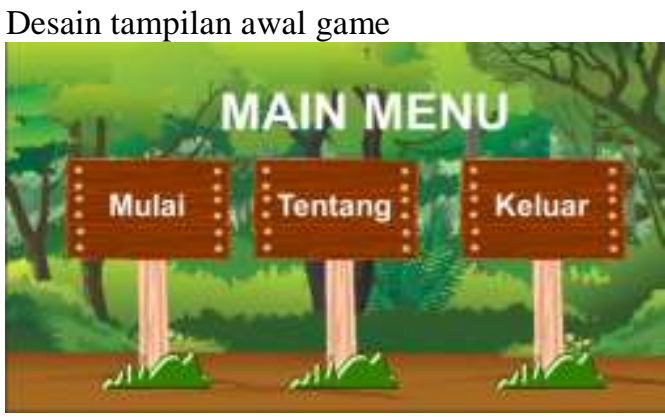

Gambar 4. Main Menu

Main menu merupakan tampilan yang akan pertama muncul ketika membuka game. Terdapat 3 button yang masing-masing memiliki fungsi berbeda. Button mulai berfungsi untuk mengawali game, button mulai ini akan mengarah menuju scene selanjutnya. Kemudian pada button tentang memberikan informasi mengenai game atau penjelasan singkat game tersebut. Terakhir button keluar berfungsi untuk meutup game atau keluar dari aplikasi game.

Tabel 1. Main menu

\begin{tabular}{|c|c|}
\hline Menu Menu & Penjelasan \\
\hline Mulai & Memulai permainan \\
\hline Tentang & Penjelasan game \\
\hline Keluar & Keluar dari game \\
\hline
\end{tabular}




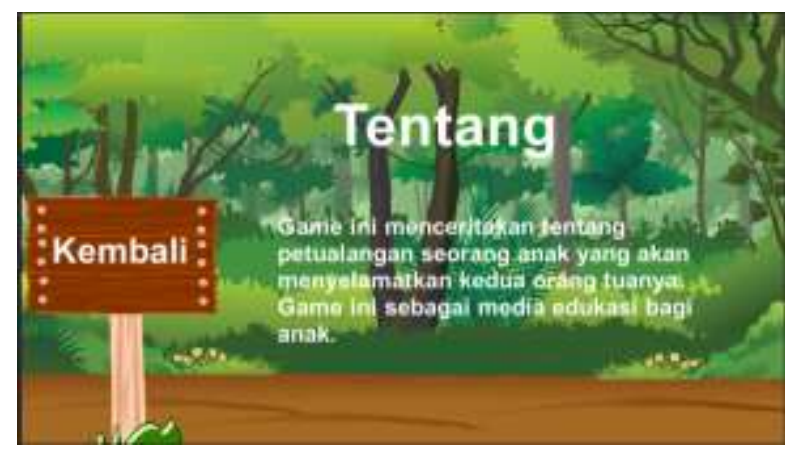

Gambar 5. Menu Tentang

Tampilan menu tentang merupakan deskripsi singkat dari game. Menjelaskan cerita secara ringkas sehingga pemain dapat dengan mudah mengetahui alur game tersebut. Terdapat tombol kemabali yang digunakan untuk menuju tampilan main menu.

\section{Tampilan Game Over}

Tahapan berikutnya yaitu tampilan akhir, tampilan ini akan muncul apabila player terkena musuh. Tampilan game over ini berupa :

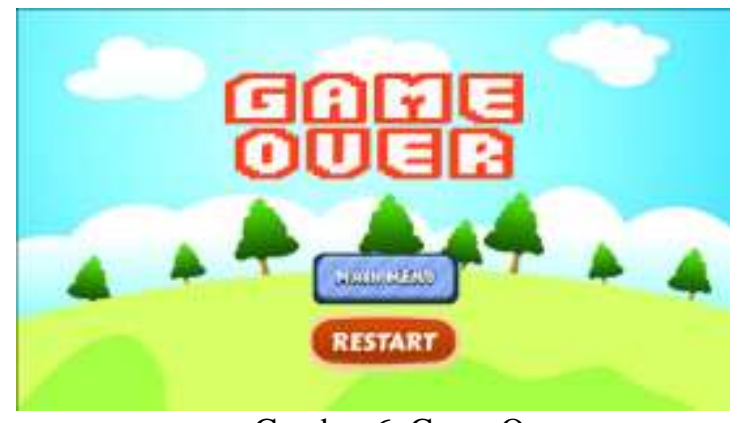

Gambar 6. Game Over

Pada tampilan Game over terdapat dua button yang digunakan yaitu button pertama main menu, yang mana button ini ketika di klik maka akan mengarahkan user menuju tampilan main menu. Sedangkan button kedua restart yang berfungsi untuk pengulanagan game, jika player mati maka permainan berakhir maka untuk bermain lagi dapat menekan button restart supaya tidak perlu lagi ke tampilam main menu.

Tabel 2. Game Over

\begin{tabular}{|c|c|}
\hline Game Over & Penjelasan \\
\hline Main menu & Mengarah ke main menu \\
\hline Restart & Pengulangan game \\
\hline
\end{tabular}

\section{Tampilan Mulai Game}

Ketika button Mulai ditekan maka pemain akan masuk ke dunia game dan dapat langsung memainkannya. Pada saat memainkan game akan terdapat tampilan karakter di dalam hutan. Terdapat ranjau yang harus dihindari oleh pemain apabila pemain terkena maka game over. Kemudian karakter akan betemu dengan orangtua yang membutuhkan pertolongan. Dan berusaha membantu orangtua tersebut. Game akan terus berlanjut sampai si karakter terkena ranjau sehingga game over.

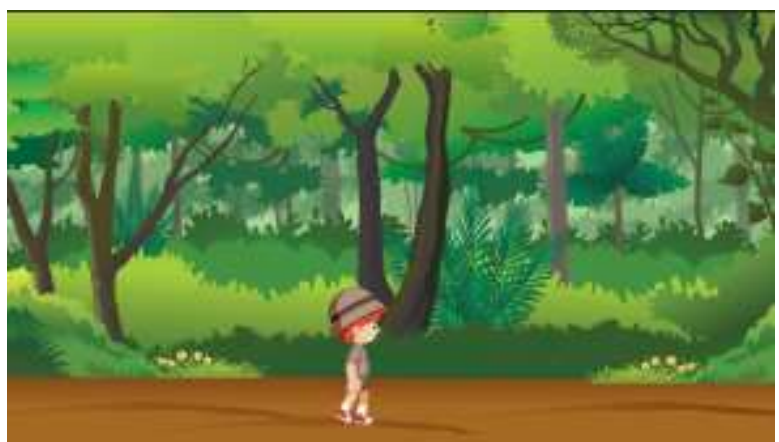

Gambar 7. Mulai Game

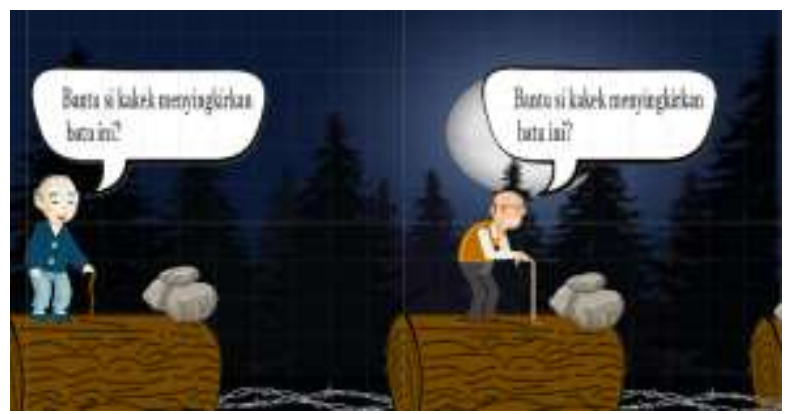

Gambar 8. Membantu orangtua.

Tabel. 3. Pengujian Button

\begin{tabular}{|c|c|c|c|}
\hline No & Tombol & Hasil & Keterangan \\
\hline 1 & Mulai & $\begin{array}{l}\text { Mulai } \\
\text { game }\end{array}$ & Berhasil \\
\hline 2 & & $\begin{array}{c}\text { Tampilan } \\
\text { Tentang }\end{array}$ & Berhasil \\
\hline 3 & & $\begin{array}{l}\text { Keluar } \\
\text { Game }\end{array}$ & Berhasil \\
\hline
\end{tabular}




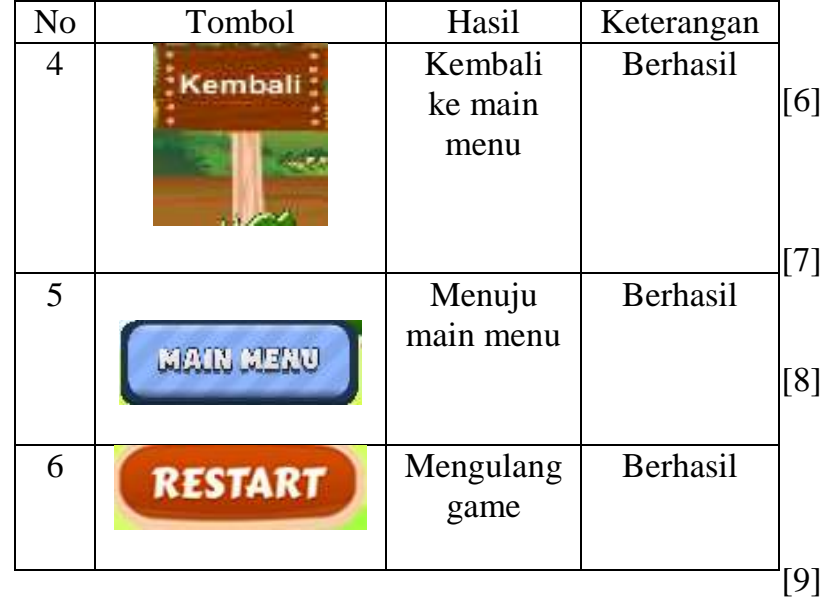

\section{KESIMPULAN}

Berdasarkan pengujian game yang telah dilakukan game berfungsi secara baik dan pemeliharaan diperlukan untuk membantu dalam pengembangan game kedepannya. Penelitian perancangan game dilakukan secara sistematis dan berurutan. Dapat diamati pada gambar 1 .

Berdasarkan penelitian mengenai pembuatan game 2 dimensi edukasi maka dapat diambil kesimpulan bahwa game yang dibuat bergenre petualang. Perancangan game petualangan anak dibuat dengan metode waterfall. Game dikemas dengan mudah untuk dipahami anak-anak berkaitan mengenai tolong-menolong kepada orangtua. Game ini membantu pendidik dalam mengajarkan nilai suka menolong terhadap yang lebih tua kepada anak-anak. Sehingga menjadi edukasi yang dapat diimplementasikan dalam kehidupan sehari-hari.

\section{DAFTAR PUSTAKA}

[1] S. Ai, E. Santoso, G. S. B. M, and R. I. Eng, "Pembuatan Game dengan Menerapkan Metode Decision Tree: UCB1 , untuk Menentukan Pemilihan," 2017.

[2] A. . Kevin, "Aplikasi Game Edukasi Bahasa Inggris Berbasis Macromedia Flash Menggunakan Metode Waterfall," SimkiTechsain, vol. 1, no. 7, pp. 1-10, 2017.

[3] R. Supardi, "Pembuatan Game Balap Kelinci dengan Unity Berbasis Android," J. Ilm. Rekayasa dan Manaj. Sist. Inf., vol. 7, no. 1, pp. 19-26, 2021.

[4] Muliadi, "Pembutan Geme Platformer BEYOND ' Mengguanakan Unity dengan xbox 360 Controller," J. Ilmu Komput. dan Sist. Infromasi, pp. 348-356, 2016.

[5] L. S. Mongi, A. S. M. Lumenta, and A. M. Sambul, "Rancang Bangun Game Adventure of Unsrat Menggunakan Game Engine Unity," J.
Tek. Inform., vol. 13, no. 1, 2018, doi: 10.35793/jti.13.1.2018.20191.

A. Suryadi, "Perancangan Aplikasi Game Edukasi Menggunakan Model Waterfall," $J$. Petik, vol. 3, no. 1, p. 8, 2018, doi: 10.31980/jpetik.v3i1.352.

T. Ardyanto and A. R. Pamungkas, "Pembuatan Game 2D Petualangan Hanoman Berbasis Android," vol. 23, no. 2, pp. 14-17, 2017.

J. I. Informatika and D. Anyangsen, "Aplikasi Game Edukasi Belajar Menghafal Huruf dan Angka Berbasis Android dengan Metode Prototype Master Edison Siregar 1," vol. IV, no. 2, pp. 1-8, 2019.

B. Pane, X. Najoan, and S. Paturusi, "Rancang Bangun Aplikasi Game Edukasi Ragam Budaya Indonesia," J. Tek. Inform., vol. 12, no. 1, 2017, doi: 10.35793/jti.12.1.2017.17793.

[10] A. Nugroho and B. A. Pramono, "Aplikasi Mobile Augmented Reality Berbasis Vuforia Dan Unity Pada Pengenalan Objek 3D Dengan Studi Kasus Gedung M Universitas Semarang," J. Transform., vol. 14, no. 2, p. 86, 2017, doi: $10.26623 /$ transformatika.v14i2.442. 